\title{
Analysis of Students' Mathematical Resilience through Google Classroom-Based Learning during the Covid- 19 Pandemic
}

\author{
Joko Soebagyo ${ }^{1}$, Sigid Edy Purwanto ${ }^{2}$, Azis Ibrahim ${ }^{3}$, Detriana Senja Purnama ${ }^{4}$, Harita \\ Audheia Akbari ${ }^{5}$, Gunawan Suryoputro ${ }^{6}$, Desvian Bandarsyah ${ }^{7}$, Samsul Maarif ${ }^{8}$, Imas Ratna \\ Ernawati $^{9}$, Maryanti Setyaningsih ${ }^{10}$, Acep Kusdiwelirawan ${ }^{11}$, Andi Hutari ${ }^{12}$, Subhan Ajiz \\ Awaludin ${ }^{13}$, Wahyu Dian Laksanawati ${ }^{14}$, Devi Anugrah ${ }^{15}$, Ayu Tsurayya ${ }^{16}$, Mayarni ${ }^{17}$, Asih \\ Miatun $^{18}$, Slamet Soro ${ }^{19}$, Ishaq Nuriadin ${ }^{20}$, Luthfi Sapahi ${ }^{21}$, Cianda Adrin Burhendi ${ }^{22}$, Supiat ${ }^{23}$, \\ Gufron Amirullah ${ }^{24}$, Susanti Murwitaningsih ${ }^{25}$, Meyta Dwi Kurniasih ${ }^{26}$, Husnin Nahry \\ Yarza $^{27}$, Agus Pambudi ${ }^{28}$, Edi Supriadi ${ }^{29}$, Hilman Faruq ${ }^{30}$, Trisna Roy Pradipta ${ }^{31}$, Esti Ambar \\ Nugraheni ${ }^{32}$, Maesaroh ${ }^{33}$, Ranti An Nisaa ${ }^{34}$, Wahidin ${ }^{35}$, Rosi Feirina Ritonga ${ }^{36}$, Nyai \\ Suminten $^{37}$, Suci Lestari ${ }^{38}$, Liszulfah Roza ${ }^{39}$, Hella Jusra ${ }^{40}$, Ayu Faradillah ${ }^{41}$, Fitri Alyani ${ }^{42}$, \\ Sugianto $^{43}$, Syafika Ulfah ${ }^{44}$, Windia Handi ${ }^{45}$, Krisna Satrio Perbowo ${ }^{46}$, Mirzanur Hidayat ${ }^{47}$, \\ Hendrik $^{48}$, Yuni Astuti ${ }^{49}$, Isnaini Handayani ${ }^{50}$, Martin $^{51}$, Eka Kartikawati ${ }^{52}$ \\ \{joko_soebagyo@uhamka.ac.id ${ }^{1}$ \}
}

Universitas Muhammadiyah Prof Dr Hamka, Indonesia

\begin{abstract}
The purpose of this study was to determine the differences in the mathematical resilience of male and female students using Google Classroom-based scientific learning. This research was conducted at SMA Negeri 1 Kopo even semester in the 2019-2020 school year. The method used was a qualitative descriptive method using a questionnaire in the form of an online survey via Google form. The questionnaire was given to students who were learning online in mathematics. The population taken was all students of class XI MIA SMA Negeri 1 Kopo. Sampling using a purposive sampling technique that was a technique of determination and sampling determined by the researcher with certain considerations. The sample consisted of 30 students. The research instrument consisted of 20 statements that refer to indicators of resilience. The conclusion obtained was that the average mathematical resilience of male students is greater than female students, with the difference being 0.715 for male students and 0.713 for female students.
\end{abstract}

Keywords: Mathematical Resilience; Google Classroom; Covid-19

\section{Introduction}

The world of education in various countries, especially Indonesia, is currently experiencing serious obstacles. The Novel Corona virus pandemic that emerged in December 2019 (Covid-19) is causing public devastation and having an impact on health worldwide [1]. Many schools, both public and private, have experienced temporary closures to stop the spread of the corona virus. Since March 2020 until now, all access to learning is carried out online. This of course has resulted in a decline in the quality of the education system. The education system will be disrupted because all subjects covered in a curriculum will be hampered by the 
process of teaching and learning activities. One of the subjects in the curriculum is mathematics which is the main subject from kindergarten education to High School education.

The Covid-19 pandemic opens opportunities and opportunities for students to be able to reflect on mathematics learning that has been received in the classroom because mathematics has its own language [2]. Face-to-face learning from March to the end of the even semester has been temporarily suspended, forcing teachers and students to do online learning. Online learning designs that are not ready and have never been done before have resulted in many complaints, both for students and teachers. Many people find it difficult to take part in mathematics learning, where they show anxiety about mathematical concepts and reasoning [3]. Students' difficulties in learning online must be addressed considering that each student has a different character and type of learning, this difference will affect the learning outcomes achieved.

Some students have experiences that are less pleasant but it is inevitable in the learning process [4]. Efforts to study mathematics in the learning process require reasoning skills as well as a resilient nature. Mathematical resilience is an internal factor that is very important in learning mathematics in addition to the factors of reasoning ability and understanding [5]. The internal factors in each student are of course different, especially for male and female students. These factors are physiological factors, which are innate as well as psychological factors that are intellectual and non-intellectual in nature [6].

Mathematical resilience is an adaptation of a positive human attitude that allows him to overcome all forms of distractions and challenges that usually arise when learning mathematics. Mathematical resilience is a pragmatic construct designed to provide anyone concerned with helping people learn and use something to work, something to develop in students to counter the many current historical destructive influences. Mathematical resilience allows students to become mathematical thinkers so that they can work against mathematical anxiety, and also provoke students' willingness to engage with mathematics [3].

The characteristics and willingness of students that can be categorized into positive things include value, fighting power (resilience) and growth. So that students with low mathematical resilience will not support the character growth of perseverance, persistence and pressure resistance in the face of difficulties or obstacles in learning mathematics. On the other hand, a person with high mathematical resilience will be able to look for, try hard and stay calm in facing the math problems he is facing because he is supported by the character of a diligent and persistent attitude when facing difficulties [7].

In this study, the writer intends to see the differences in the mathematical resilience of male and female students during the current covid-19 pandemic. The indicators in mathematical resilience in this paper [8] are as follows: a). Demonstrate a diligent, confident / confident attitude, work hard and don't give up easily in facing problems, failures and uncertainties; b). Demonstrates a desire to be sociable, easy to provide assistance, discuss with peers, and adapt to their environment; c). Come up with new ideas / ways and look for creative solutions to challenges; d). Using the experience of failure to build self-motivation, e). Have curiosity, reflect, research, and make use of various sources; f). Have the ability to control themselves, are aware of their feelings.

There are three key factors for developing mathematical resilience, namely: choosing and determining what they will do to train it, and engaging in the learning process, both in attitudes and values [9]. In online learning through Google Classroom, of course these three keys cannot be fully fulfilled, but it does not rule out that some students are more resilient when learning online. Evidence shows that math resilience can be developed in students who are willing to put in effort and make an effort to produce improvement [3]. 
Some students expressed a lack of confidence: "I was never confident in math"; "I wasn't good at math, even when I was in elementary school" [10]. This is of course the biggest challenge, how students will try and try, belief in mathematics is not there. The solution to this math problem requires identification so that there is compatibility [11].

In the context of learning, resilience is the concept of students' ability to face problems and obstacles in the learning process [12]. In this section, the author wants to see the differences in mathematical resilience of male and female students with the following problem formulations:

a. What is the Mathematical Resilience of Students during Online Learning through Google Classroom-based learning media during the Covid-19 period?

b. Are there differences in the mathematical resilience of male students and female students through Google Classroom-based learning media during the Covid-19 period?

\section{Method}

The research method used in this research is descriptive qualitative using purposive sampling technique, which is a technique of determining and taking samples that are determined by the researcher with certain considerations. Purposive sampling technique is a type of non-probability sampling that is most effective when one needs to study a specific cultural domain with knowledgeable experts in it [13]. The research instrument used was an online questionnaire in Google form format. The samples taken were students of XI MIA SMA Negeri 1 Kopo with a total number of students as many as 30 people. The questionnaire was given to students who were learning online in mathematics. The questionnaire given consists of 20 statements with answer options: strongly agree, agree, disagree, and strongly disagree.

The indicators of the questionnaire consist of six indicators, namely: 1) Perseverance, confidence / confidence, working hard, not giving up easily in facing problems, failures and uncertainties during the Covid-19 pandemic; 2) Willing to be social, easy to help discussing with peers and adapting to their environment during the Covid-19 pandemic; 3) Come up with new ideas / ways and find creative solutions to challenges; 4) Using the experience of failure to build self-motivation; 5) Shows curiosity, reflects, researches, makes use of various sources; 6) Having the ability to speak, self-control and aware of his feelings.

Table 1. Google Classroom Based Learning Feedback Questionnaire

\begin{tabular}{|c|c|c|}
\hline Indicator & $\begin{array}{c}\text { No. } \\
\text { Item }\end{array}$ & Statements \\
\hline \multirow{2}{*}{1} & 3 & $\begin{array}{r}\text { I try to do the math problems myself until I finish it even though I } \\
\text { need to work hard through google classroom media. }\end{array}$ \\
\cline { 2 - 3 } & 6 & $\begin{array}{r}\text { I doubt I can arrange math problems through google classroom } \\
\text { media as well as other friends' work. }\end{array}$ \\
\cline { 2 - 3 } & 9 & $\begin{array}{c}\text { I am trying to improve my math assignment through google } \\
\text { classroom which is not yet perfect, although it requires hard work. }\end{array}$ \\
\hline 2 & 13 & $\begin{array}{c}\text { I find it difficult to find friends to ask for help with learning math } \\
\text { difficulties. }\end{array}$ \\
\hline 3 & 17 & I tried a different way from the example in the math textbook \\
through google classroom media.
\end{tabular}




\begin{tabular}{|c|c|c|}
\hline Indicator & $\begin{array}{l}\text { No. } \\
\text { Item }\end{array}$ & Statements \\
\hline & 18 & I feel safer doing assignments like a friend who is good at math. \\
\hline & 20 & $\begin{array}{l}\text { I deliberately chose open-ended math practice questions as an } \\
\text { exercise in creative thinking. }\end{array}$ \\
\hline \multirow{4}{*}{4} & 23 & $\begin{array}{l}\text { I am anxious about learning math's after getting bad scores in my } \\
\text { last math test through google classroom media. }\end{array}$ \\
\hline & 24 & $\begin{array}{l}\text { I practiced even harder after solving difficult math problems } \\
\text { incorrectly through google classroom media. }\end{array}$ \\
\hline & 25 & I think failing past math exams is a valuable experience. \\
\hline & 26 & $\begin{array}{l}\text { I reworked solving math problems through google classroom which } \\
\text { was wrong even though it took a long time. }\end{array}$ \\
\hline \multirow{6}{*}{5} & 28 & $\begin{array}{l}\text { I tried to compare explanations of the same math topic from } \\
\text { various books. }\end{array}$ \\
\hline & 29 & I am tired of studying mathematics from various books. \\
\hline & 30 & $\begin{array}{l}\text { I am grateful to find articles on the internet that are relevant to my } \\
\text { math assignment. }\end{array}$ \\
\hline & 32 & $\begin{array}{l}\text { I am confused about learning different explanations from various } \\
\text { math books through google classroom media. }\end{array}$ \\
\hline & 33 & $\begin{array}{l}\text { I am desperate to find relevant resources for solving math } \\
\text { assignments through google classroom media. }\end{array}$ \\
\hline & 35 & $\begin{array}{l}\text { I avoid trying new ways to prove math problems that don't know } \\
\text { the result through google classroom media. }\end{array}$ \\
\hline \multirow{3}{*}{6} & 36 & $\begin{array}{l}\text { I was annoyed when I got harsh criticism of my math work through } \\
\text { google classroom media. }\end{array}$ \\
\hline & 38 & $\begin{array}{l}\text { I find it difficult to express my understanding of mathematics to } \\
\text { others. }\end{array}$ \\
\hline & 40 & $\begin{array}{l}\text { I gave up hope when I failed to defend my math (solving problems) } \\
\text { idea in front of the class directly. }\end{array}$ \\
\hline
\end{tabular}

Table 1 shows the mathematical resilience indicator instruments of male and female students at high school (SMA) during online learning which are classified into 6 indicators with 20 validated question items from the 40 question items offered during the questionnaire. The achievement indicator contained in this instrument is to calculate the percentage of the responses to the students' mathematical resilience questionnaire during online learning.

To calculate the percentage of students' mathematical resilience responses, it is necessary to have questionnaire results that have been tested for validity and reliability with the following formula:

$$
P=\frac{n}{N} \times 100 \%
$$

Where:

$\mathrm{P}=$ percentage of indicator of resilience

$\mathrm{n}=$ the number of students who choose questions from the questionnaire

$\mathrm{N}=$ the number of all students who took part in the questionnaire / questionnaire 
The percentage of students' mathematical resilience indicators can be classified or categorized into levels, based on the table as follows [14]:

Table 2. Student Mathematical Resilience Interval

\begin{tabular}{cc}
\hline Interval & Category \\
\hline $85-100 \%$ & Very High \\
\hline $75-84 \%$ & High \\
\hline $60-74 \%$ & Moderate \\
\hline $40-59 \%$ & Low \\
\hline $0-39 \%$ & Very Low \\
\hline
\end{tabular}

From Table 2, it is found that the level of mathematical resilience of high school students reaches very high if in the $85-100 \%$ interval, the moderate level is in the $60-74 \%$ interval and does not have mathematical resilience or is very low if it is in the $0-39 \%$ interval. The design of this research stage is according to the following flow chart as shown in Figure 1.

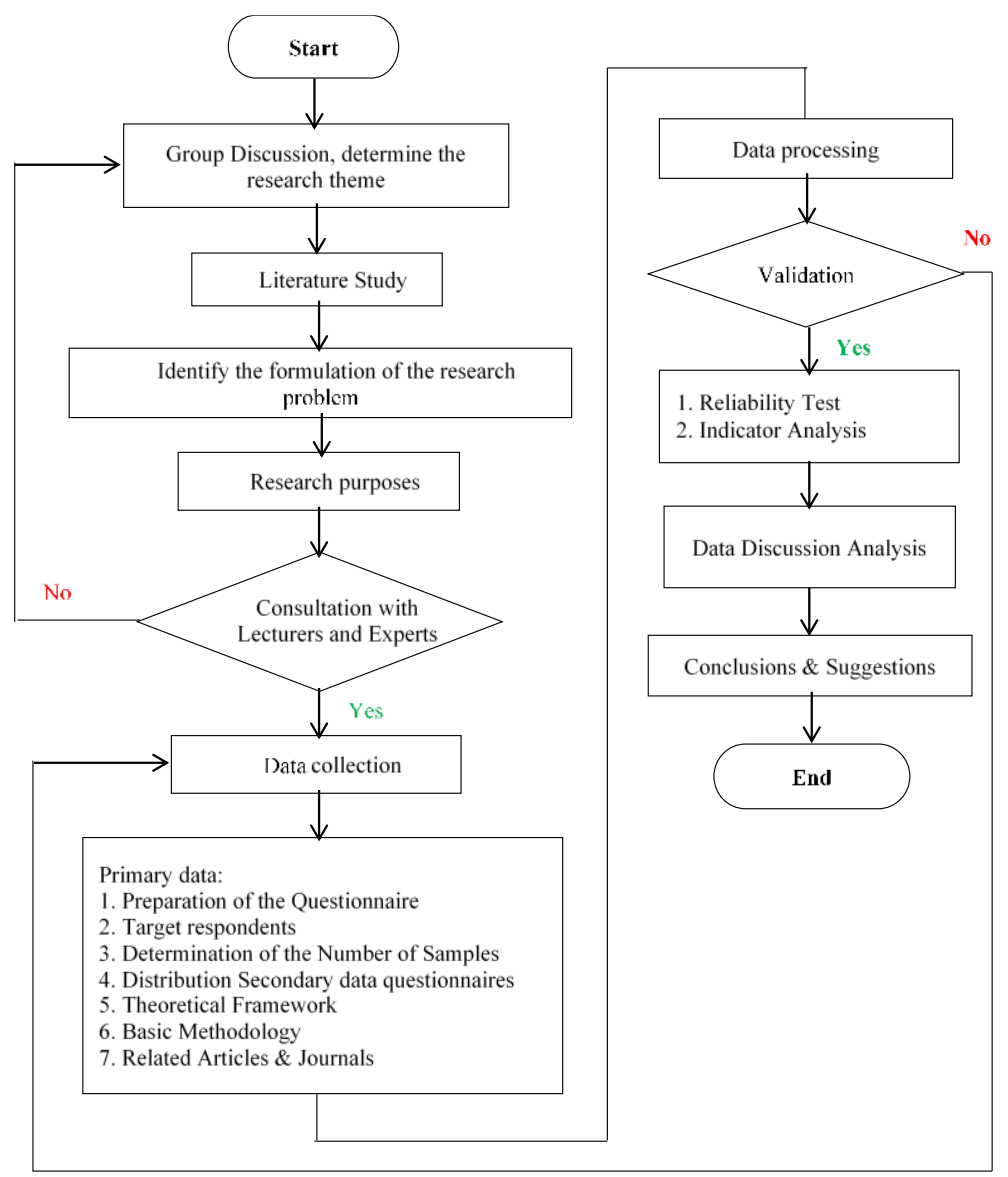

Fig 1. Research Flowchart 


\section{Result and Discussion}

As previously stated, this research was conducted to see the differences in the mathematical resilience of male and female students using Google Classroom-based scientific learning. The descriptive statistics of the results from the mathematical resilience questionnaire of male and female students can be seen in Table 3.

Table 3. Descriptive Statistics of Students' Mathematical Resilience

\begin{tabular}{|l|c|c|}
\hline \multicolumn{1}{|c|}{ Gender } & N & Mean \\
\hline Male & 15 & 0,715 \\
\hline Female & 15 & 0,713 \\
\hline
\end{tabular}

Based on the results of the analysis of the questionnaire that had been filled in by the students, it was found that the average mathematical resilience of male students was greater than that of female students, which can be seen in Table 4.

Table 4. Percentage of Mathematical Resilience Indicators

\begin{tabular}{|l|l|c|c|}
\hline No & \multicolumn{1}{|c|}{ Indicator } & Male (\%) & Female (\%) \\
\hline 1. & $\begin{array}{l}\text { Being diligent, confident / confident, working hard, not } \\
\text { giving up easily in facing problems, failures and } \\
\text { uncertainties during the Covid-19 pandemic. }\end{array}$ & 79 & 75,67 \\
\hline 2. & $\begin{array}{l}\text { Wanting to socialize, easy to help discuss with peers and } \\
\text { adapt to their environment during the Covid-19 } \\
\text { pandemic. }\end{array}$ & 60 & 63 \\
\hline 3. & $\begin{array}{l}\text { Come up with new ideas / ways and look for creative } \\
\text { solutions to challenges. }\end{array}$ & 71,67 & 71,67 \\
\hline 4. & Using failure experiences to build self-motivation & 79,50 & 78 \\
\hline 5. & $\begin{array}{l}\text { Shows curiosity, reflects, researches, makes use of } \\
\text { various sources. }\end{array}$ & 67,83 & 68 \\
\hline 6. & $\begin{array}{l}\text { Having language skills, self-control and aware of his } \\
\text { feelings. }\end{array}$ & 65 & 67,33 \\
\hline
\end{tabular}

Based on the results of the analysis that has been carried out that there are differences in mathematical resilience between male and female students, it can be seen from the descriptive statistical data that male students have a higher average resilience than female students. In the first indicator, male have a percentage of $79 \%$ and female $75.67 \%$ as shown in Figure 2.

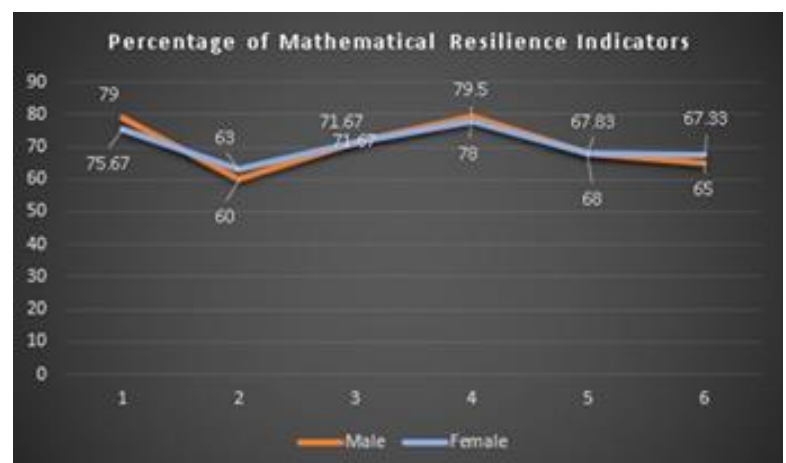

Fig 2. Percentage Graph of Mathematical Resilience Indicators 
This means that male students are more diligent, confident / confident, work hard, do not give up easily in facing problems, failures and uncertainties during the Covid-19 pandemic than female students. This percentage is consistent with the theory that a lack of trust in girls in Mathematics persists despite efforts to involve girls differently, to increase achievement and participation rates, and to get rid of harmful gender bias messages. Despite experiencing math achievement, girls still show less confidence in their abilities than boys, and in fact, males tend to show higher self-confidence while females tend to show less self-confidence. This is evidenced when students are given a math problem to solve and then asked how confident they are in their answer. Boys articulate certainty and confidence in their answers even when their answers turn out to be wrong and girls show a lack of certainty or self-confidence, when their answers turn out to be correct and some even ask for opportunities to re-examine their work [15].

In the second indicator, namely the desire to socialize, easily provide assistance to discuss with peers and adapt to their environment during the Covid-19 pandemic, the percentage of male students is $60 \%$ and female students is $63 \%$ as shown in Figure 2. This is in accordance with the theory which states that high-level achievement in mathematics requires the ability to communicate effectively and understand abstract ideas, so that women's excellence in writing should be able to help in all academic fields. Meanwhile, males outperform females on most measures of visuospatial ability, which has been implicated as contributing to gender differences on standardized tests in mathematics. The evolutionary account of sex differences in mathematics supports the conclusion that, although sex differences in mathematics have not directly evolved, they (males and females) can be indirectly related to differences in interests and specific brain and cognitive systems [16].

The third indicator, which is coming up with new ideas / ways and finding creative solutions to challenges, has the same percentage of male students at $71.67 \%$ and female students at $71.67 \%$. This indicates that there is an indication that male students 'mathematical creative thinking skills have a positive effect on mathematics learning achievement, with an $\mathrm{R}$ coefficient of $57.7 \%$, variations in mathematics learning achievement can be explained by variations in male students' creative thinking abilities; 3) The mathematical creative thinking ability of female students has a positive effect on mathematics learning achievement, with an $\mathrm{R}$ coefficient of $56 \%$, variations in mathematics learning achievement can be explained by variations in female students' creative thinking abilities. Male variations in creative thinking are slightly superior to women's variations in creative thinking [17].

Male students have a higher percentage than female students in the fourth indicator, which is coming up with new ideas / ways and finding creative solutions to challenges with male students at $79.50 \%$ and female students at $78 \%$. This is in line with male and female students with high ability in general mathematics who are able to express situations in the form of images or mathematical models, analyze and evaluate mathematical ideas in other forms, but male and female students who have moderate and low abilities In general, mathematics still has difficulty expressing situations in the form of images or mathematical models, analyzing and evaluating mathematical ideas in other forms [18].

The fifth indicator is showing curiosity, reflecting, researching, utilizing various sources with the percentage of male students $67.83 \%$ and female students $68 \%$. Based on that percentage, male students differed from their female counterparts in their math performance. Female students are more curious (curious), motivated, and have a positive attitude towards mathematics than boys. However, there is no significant difference between the mean of men and women in all variables [19]. 
In addition, the sixth indicator, namely having language skills, self-control and being aware of their feelings, was $65 \%$ for male students and $67.33 \%$ for female students. This percentage is in line with research which states that male students have higher selfconceptions, performance expectations, intrinsic motivation, and increased ego orientation in mathematics than female students, while female students have higher intrinsic motivation to learn language than female students. male students [20].

\section{Conclusion}

From this research shows that there are differences in the mathematical resilience of male students and female students through Google Classroom-based learning media. Based on the results of data analysis, it can be concluded that there are differences in the mathematical resilience of male students and female students. It supports the descriptive statistics that the percentage of male students is higher than female students. Male students have more: 1) a diligent attitude, confident / confident, working hard, not giving up easily in facing problems, failures and uncertainties during the Covid-19 pandemic; 2) Willing to be social, easy to help discussing with peers and adapting to their environment during the Covid-19 pandemic; 3) Come up with new ideas / ways and find creative solutions to challenges; 4) Using the experience of failure to build self-motivation; 5) Shows curiosity, reflects, researches, makes use of various sources; 6) Having the ability to speak, self-control and aware of his feelings.

In general, the mathematical resilience of male and female students at SMA Negeri 1 Kopo is in the medium category, namely 60 to $74 \%$ based on the mathematical resilience interval table, this shows that there is still a sense of being diligent, persistent and calm when facing problems so that students are good enough to explore looking for creative and innovative problem solving. In addition, students are also quite skilled and good at language to convey messages or information to peers, teachers, school principals and other people around the school environment during the Covid-19 pandemic.

\section{References}

[1] C. N. Ngonghala et al., "Mathematical Assessment of The Impact of Non-Pharmaceutical Interventions on Curtailing The 2019 Novel Coronavirus," Math. Biosci., vol. 325, no. May, p. 108364, 2020.

[2] K. S. Asih, Isnarto, Sukestiyarno, and Wardono, "Resiliensi Matematis pada Pembelajaran Discovery Learning dalam Upaya Meningkatkan Komunikasi Matematika," Prism. Pros. Semin. Nas. Mat., vol. 2, pp. 862-868, 2019.

[3] S. Johnston-Wilder and C. Lee, "Developing Mathematical Resilience," in BERA Annual Conference 2010, 1-4 Sep 2010, University of Warwick, 2010.

[4] A. J. B. Hutauruk, "Perilaku Resiliensi Matematis Mahasiswa Melalui Model Problem-Based Learning Dengan Pendekatan Metakognitif," Sepren, vol. 1, no. 01, pp. 7-16, 2019.

[5] E. P. Cahyani, W. D. Wulandari, E. E. Rohaeti, and A. Y. Fitrianna, "Hubungan Antara Minat Belajar Dan Resiliensi Matematis Terhadap Kemampuan Pemahaman Matematis Siswa Kelas Viii Smp," J. Numer., vol. 5, no. 1, pp. 49-56, 2018.

[6] L. S. Zanthy, "Kontribusi Resiliensi Matematis Terhadap Kemampuan Akademik Mahasiswa Pada Mata Kuliah Statistika Matematika," Mosharafa J. Pendidik. Mat., vol. 7, no. 1, pp. 85-94, 2018. 
[7] H. Hendriana, U. Sumarmo, C. Carli, M. G. Ristiana, and H. D. Putra, "Enhancing Students Mathematical Creative Skill and Resilience by Using Problem Posing Approach,” J. Phys. Conf. Ser., vol. 1318, no. 1, 2019.

[8] S. Maharani and M. Bernard, "Analisis Hubungan Resiliensi Matematik Terhadap Kemampuan Pemecahan Masalah Siswa Pada Materi Lingkaran,” JPMI (Jurnal Pembelajaran Mat. Inov., vol. 1, no. 5, p. 819, 2018.

[9] A. Wibowo, I. Slamet, and I. Sudjadi, "Construct Validity of Mathematical Resilience: Confirmatory Factor Analysis,” vol. 160, no. Incomed 2017, pp. 261-264, 2018.

[10] S. Johnston-Wilder and J. Brindley, "Developing Mathematical Resilience in School-Students Who have Experienced Repeated Failure," no. April 2017, 2015.

[11] A. Ramful, "Quantitative Relationships Involving Additive Differences: Numerical Resilience Theoretical Framework: Quantitative Reasoning Method," pp. 533-540, 2014.

[12] A. J. B. Hutauruk and N. Priatna, "Mathematical Resilience of Mathematics Education Students," J. Phys. Conf. Ser., vol. 895, no. 1, 2017.

[13] M. D. C. Tongco, "Purposive Sampling as A Tool for Informant Selection," Ethnobot. Res. Appl., vol. 5, pp. 147-158, 2007.

[14] C.- Rahmawati and L. S. Zhanty, "Analisis Kemamampuan Komunikasi Siswa Menengah Terhadap Resiliensi Matematis,” JPMI (Jurnal Pembelajaran Mat. Inov., vol. 2, no. 3, p. 147, 2019.

[15] L. E. Hart, "Classroom Processes, Sex of Student, and Confidence in Learning Mathematics," J. Res. Math. Educ., vol. 20, no. 3, pp. 242-260, 2020.

[16] D. F. Halpern, C. P. Benbow, D. C. Geary, R. C. Gur, J. S. Hyde, and M. A. Gernsbacher, " $<$ Halpern Et Al. 2007 Sex Difference of Verbal and Math Skills.Pdf $>$," vol. 8, no. 1, pp. 1-51, 2007.

[17] Marzuki, E. Cahya, and Wahyudin, "Relationship Between Mathematical Creative Thinking Ability and Student's Achievement in Gender Perspective," J. Phys. Conf. Ser., vol. 1521, no. 3, 2020.

[18] N. H. Firdiani, T. Herman, and A. Hasanah, "Gender and Mathematical Communication Ability," J. Phys. Conf. Ser., vol. 1521, no. 3, 2020.

[19] M. C. A. Jaen, "Curiosity, motivation, attitude, gender, and mathematics performance," Norm. Light., vol. 10, no. 2, pp. 89-103, 2016.

[20] S. Skaalvik and E. M. Skaalvik, "Gender Differences in Math and Verbal Self-Concept, Performance Expectations, and Motivation,” Sex Roles, vol. 50, no. 3-4, pp. 241-252, 2004. 